PROBLEMS

OF EDUCATION IN THE $21^{\text {st }}$ CENTURY Vol. 80 , No. 1,2022

\title{
AN ENTREPRENEURIAL SCIENCE THINKING MODULE BASED ON THE SOCIOSCIENTIFIC ISSUES APPROACH WITH THINKING WHEEL MAP FOR PRIMARY SCHOOL STUDENTS IN STEM EDUCATION
}

Jamilah Ahmad, Nyet Moi Siew

University Malaysia Sabah, Malaysia

\begin{abstract}
The design and development of modules in cultivating entrepreneurial science thinking (EST) in STEM education at the primary school level is still limited. Thus, this research was conducted to i) establish the validity, reliability and feasibility of the module based on the socioscientific issues approach aided by the thinking wheel map (SIA-TM), and ii) evaluate its effects on the EST among fifth graders in STEM education. Data were collected via respondents'feedback in the 5-point Likert scale questionnaire and an EST test. The first phase of the module evaluation was conducted by five expert evaluators and among 30 fifth graders. The second phase was evaluation through the quasi-experimental research design with the pre-test post-test control group design. A total of 60 fifth graders were gathered into two groups which were the SIA-TM group $(n=30)$ and control group $(n=30)$. The results of the SIA-TM module evaluation shows that the validity value was good, and the alpha Cronbach reliability was between .74 and .89 with the overall value of .92. The students showed a high level of acceptance $(m=4.53)$ towards the activities in the SIA-TM Module. Feedback from the students showed the module's feasibility and acceptance by students. The results of the t-test prove a significantly positive effect on the five constructs in EST. Therefore, these results establish that the SIA-TM teaching and learning module is valid, reliable, feasible and effective in increasing fifth graders' EST in STEM education.

Keywords: entrepreneurial science thinking, socioscientific issues approach, STEM education, thinking wheel map
\end{abstract}

\section{Introduction}

Entrepreneurial thinking has gained attention in science curriculum due to the need for developing individuals who can think critically, creatively, innovatively, and inhibit high values. Entrepreneurial thinking is recognised as one of the most relevant skills that should be mastered by students to face an increasingly challenging future (Bacigalupo et al., 2016; Buang et al., 2009). This skill is not merely for the purpose of becoming an entrepreneur but is an intrinsic skill that is important for establishing human development, fulfilling the market's demands, and increasing competition (Bacigalupo et al., 2016).

Entrepreneurial science thinking, on the other hand, is not a philosophy that aims to develop only entrepreneurs, but it is a design-thinking skill based on scientific knowledge and entrepreneurial orientation (Buang et al., 2009). According to Buang et al. (2009), designing a model requires students to master five important constructs of entrepreneurial science thinking which are observation, new ideas, innovation, creativity, and values. The mastery of these constructs aids students to generate ideas, choose ideas, sketch designs, create models and evaluate the contribution of their design to society. 
Kicking off with this awareness, there arises a high need to apply entrepreneurial thinking in the curriculum (Saavedra \& Opfer, 2012). Like other countries, Malaysia is now preparing school students to be globally competitive in the $21^{\text {st }}$ century. In its Primary School Standard Curriculum 2017 edition, the element of entrepreneurial curriculum has been applied in all subjects including Science. Ironically, the module that is supposedly used to inculcate entrepreneurial science thinking in STEM education at the primary school level is very limited and restricted. Whereas Karlsson et al. (2021) stated that emphasis on innovation and entrepreneurship is incredibly significant to face the 21 st century. Thus, there is a need for compatible research that synchronises with the needs of the Malaysian Education Development Plan (2013-2025) that encourages the application of Elements Across the Curriculum in the TL process of entrepreneurship (Ministry of Education Malaysia, 2012).

Therefore, a teaching and learning (TL) module which integrates STEM, innovation and entrepreneurship needs to be introduced in the school curriculum for students to become designers, innovators, and possess entrepreneurial values. In fact, emphasis on the entrepreneurial element in STEM education is another effort to attract students' interest to study STEM subjects besides studying the ways of commercialising ideas with the integration of various fields of study. Since there exist gaps and issues in implementing the application of entrepreneurial science thinking in the curriculum, a TL module that is based on socioscientific issues approach aided by a thinking wheel map (SIA-TM) was developed and its effects on entrepreneurial science thinking in STEM education was determined.

\section{Theoretical Framework}

The design and development of SIA-TM teaching and learning module based on the analysis of various elements was proposed such as the application of socioscientific issues approach, the use of thinking wheel map, the implementation of STEM education in primary schools, understanding towards the learning styles of primary school students and its relation to theories and teaching models. The SIA-TM teaching and learning module applied the concept of knowledge construction by adapting to the environment following Piaget's theory of cognitive constructivism (1976) and Vygotsky's theory of social constructivism (Vygotsky, 1978). Piaget's theory is compatible with fifth graders in this research as it focuses on the concept of using their prior knowledge to analyse socioscientific issues and design products that can solve issues presented to them. Through the discussions and solutions of socioscientific issues, students would undergo a process of exploration and recognise their own prior knowledge. The impact of this is a balance between the assimilation and accommodation processes towards new information based on their existing knowledge (Sjøberg, 2007).

In line with the students' ages (10-11 years old), Piaget's theory of cognitive constructivism states that these children are within the concrete operational stage where they are able to investigate and solve concrete problems rationally (Pascual-Leone \& Johnson, 2005). Therefore, in this research students were presented with stimulating material such as socioscientific issues and pictorials that were suitable for their cognitive stage. Additionally, in line with Vygotsky's theory of social constructivism, students were assigned into small groups to enable teamwork activities and generation of ideas. Indirectly, discussion activities in these small groups applied the social aspect into the students' learning process (Jones \& BraderAraje, 2002).

Researchers realise the importance of pedagogical principles in the process of teaching and learning (TL) in primary schools to support the process of information and knowledge construction cognitively and socially. This research applied the socioscientific issues approach (Sadler et al., 2017) and thinking wheel map (Bengston, 2016; Bloom, 1956; Glenn, 1972) in the module development. 
Jamilah AHMAD, Nyet Moi SIEW. An entrepreneurial science thinking module based on the socioscientific issues approach with thinking wheel map for primary school students in STEM education

PROBLEMS

OF EDUCATION IN THE $21^{\text {st }}$ CENTURY Vol. 80 , No. 1,2022

The socioscientific issues approach (SIA) was used because its suitability in terms of psychological, social, and emotional growth for children as well as its usability in various aspects in science education (Zeidler \& Nichols, 2009). Teachers that use SIA in learning sessions help students to develop and evaluate arguments related to current issues (Owens et al., 2017). The first phase is focused on the issue at hand. In this phase, students build their understanding by relating issues with scientific ideas and community awareness. The second phase prepares a platform for teachers to encourage their students to understand and practice science that stresses on socioscientific and community issues. In this way, students are actively involved to search for relations between social issues and scientific knowledge and practices that boosts the relevance of the issues to be solved (Sadler et al., 2017). The last phase encourages students to synthesise ideas and practices. This phase provides students opportunities to be actively involved in manifesting ideas and opinions ethically.

Through the research of Birmingham and Barton (2014) and Nam and Chen (2017), the SIA has become the chosen approach to solve scientific, technological and community issues. SIA is observed to help increase students' scientific knowledge (Driver et al., 2000; Kinslow \& Sadler, 2018; Sadler et al., 2017; Topçu et al., 2018). Scientific knowledge that is generated through socioscientific debates will drive students to produce ideas effectively because they have to relate the contributions of their inventions to real issues in society.

The thinking wheel map was adapted from Bloom (1956), Glenn (1972) and Bengston (2016). The thinking wheel map consists of a circle in the centre and five stages which could help students to produce and organise their ideas. When using the SIA-TM module, the students were given socioscientific issues for discussion and debate. Any logical and scientific ideas will be written onto the centre of the map. These scientific ideas will trigger students to contribute ideas in the next stage. Bengston (2016) stated that thinking wheel map is easily understood by students and stimulates their systematic thinking. This statement is compatible with this study's application where students needed to generate ideas in groups through brainstorming sessions. Any logical and feasible idea will be entered into each stage. Moreover, the thinking wheel map aids students to collect ideas speedily.

To integrate the socioscientific issues approach with the thinking wheel map, the researchers used the method of thorough integration (Swartz \& Parks, 1994). With this method, the entrepreneurial science thinking skill is taught together with the contents of the lesson. The thorough integration was taught in five steps, that are: (i) introduction, (ii) thinking actively, (iii) thinking about thinking, (iv) reinforcement exercise, and (v) thinking application. In this case, two components (learning content and entrepreneurial science thinking skill) are implemented as complementary in each step of the process.

In developing the unit activity in the module, the researchers applied the entrepreneurial science thinking model proposed by Buang et al. (2009), which was divided into five steps that are i) plan and do purposeful observation [Observation], ii) create ideas by looking for uniqueness or strengths [New Ideas], iii) choose ideas that can be modified or improved and evaluate those ideas [Innovation], iv) strengthen and improve good ideas in a focused manner [Creativity], and v) ensure that ideas or products are meaningful for society [Value].

The ADDIE Model (Branch, 2010) which consists of five phases that are analysis, design, development, implementation, and evaluation was adopted in the design and development of SIA-TM teaching and learning module. The ADDIE Model was selected because it focuses on student-centred learning, its learning design is goal oriented, and it enables students to show meaningful actions and solve issues practically. The theoretical framework for the design and development of the SIA-TM teaching and learning module is shown in Figure 1. 
Jamilah AHMAD, Nyet Moi SIEW. An entrepreneurial science thinking module based on the socioscientific issues approach with thinking wheel map for primary school students in STEM education

Figure 1

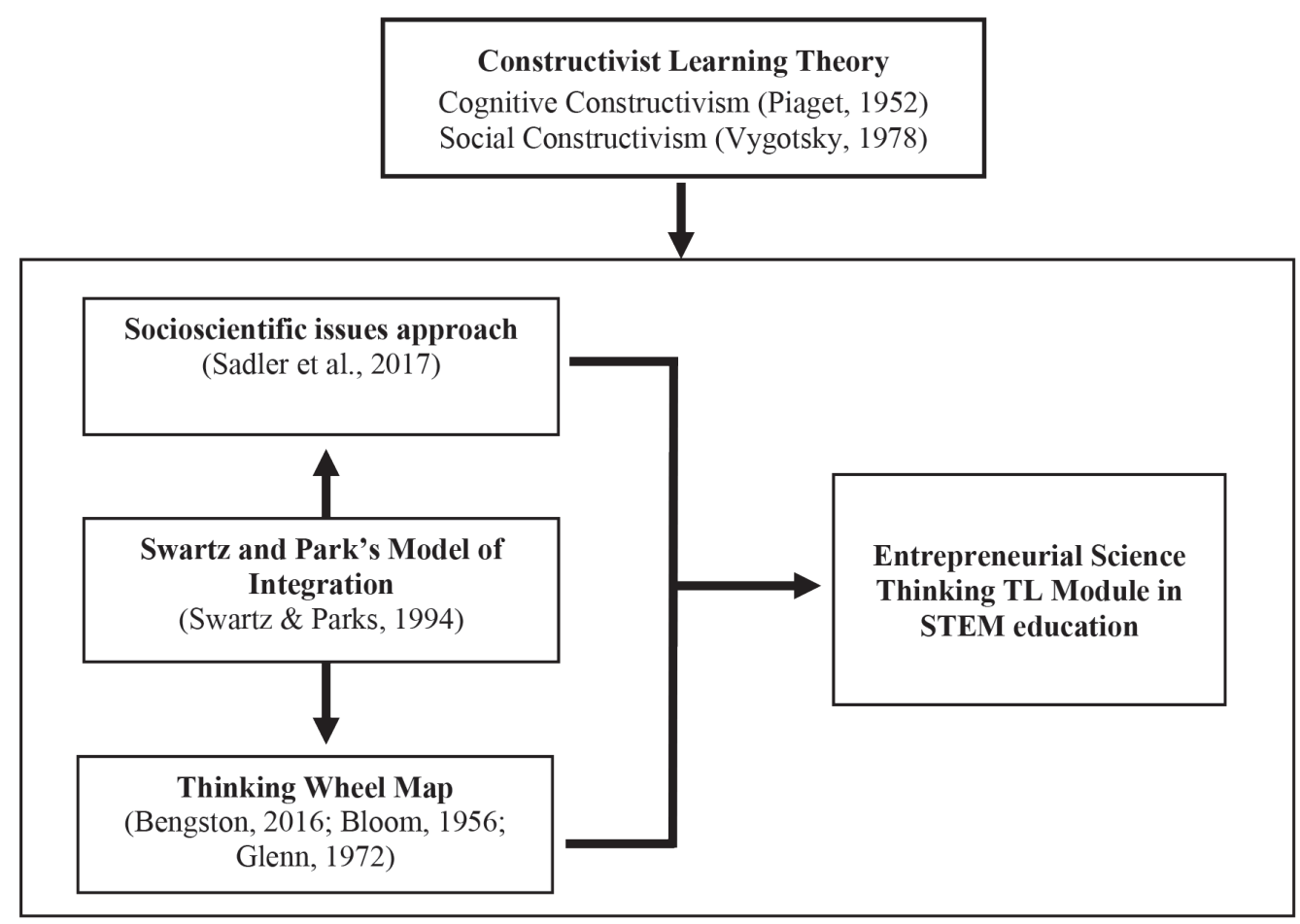

\section{Purpose and Research Questions}

This research was conducted to design and develop a teaching and learning module that integrated the socioscientific issue approach and thinking wheel map to inculcate the entrepreneurial science thinking in STEM education among fifth graders. There were three research questions that drive this study:

1. Was the SIA-TM Module valid, reliable, and feasible for fifth graders?

2. Was there a significant difference between pre-test mean scores and post-test mean scores in entrepreneurial science thinking among fifth graders who were taught i) using the SIA-TM module, and ii) those in the control group?

3. Was there a significant difference between fifth graders who were taught using the SIA-TM module and those in the control group in i) pre-test mean scores, and ii) post-test mean scores in entrepreneurial science thinking?

4. What were the fifth graders' experiences in using the SIA-TM Module in STEM education?

\section{Research Methodology}

\section{Research Design}

This research applied a descriptive and quasi-experimental research design. Descriptive design involves evaluation from the aspect of validity, reliability and feasibility of the SIA-TM teaching and learning module. Whereas the quasi-experimental research design was employed 
Jamilah AHMAD, Nyet Moi SIEW. An entrepreneurial science thinking module based on the socioscientific issues approach with thinking wheel map for primary school students in STEM education

PROBLEMS

OF EDUCATION

IN THE $21^{\text {st }}$ CENTURY Vol. 80, No. 1,2022

34

to determine the effects of SIA-TM module on fifth graders' entrepreneurial science thinking. The effects of module were determined by the fifth graders' performance in entrepreneurial science thinking test as stated in research question number Two and Three. This research was conducted over 12 weeks beginning from October to December 2020.

\section{Research Sample}

The descriptive research involved 30 fifth graders and five experts. According to Chua (2011), a total of 30 respondents are needed to measure the internal consistency or reliability of a new instrument, which is evaluated by Cronbach's alpha. Yurdugül (2008) recommended 30 as the sufficient sample size when calculating the Cronbach's alpha. This number is corroborated by Bujang et al. (2018) and Conroy (2021) who stated that a pilot testing required a minimum of 30 respondents as the sample to determine the Cronbach's alpha. A total of 60 fifth graders were involved in the quasi-experiment who were from two randomly chosen schools in Tawau, Sabah. These students were grouped in two groups that is, the SIA-TM group $(n=30)$ and control group $(n=30)$. They stood of $29(48 \%)$ males and $31(52 \%)$ females. $60 \%$ of these students' parents work in the government sector while $40 \%$ work in the private sector or are involved in the business sector.

\section{Ethical Considerations}

At the early stage of this research, the researchers obtained consent from the headmasters, teachers, and students. The students were provided letters of agreement for their parents' approval for their involvement in the research. The agreement letter detailed the students' involvement in the research and the parents' agreement showed their understanding about the study's purposes. All the respondents were informed about the confidential nature of the research and that they could pull out from the research without facing any punishment.

\section{Descriptive Research}

\section{Analysis Phase}

The main purpose for the design of SIA-TM module was to encourage and inculcate entrepreneurial science thinking among fifth graders in STEM education that is taught in the science subject. To achieve the objectives of this research, researchers conducted an analysis towards the needs of the students and context of the study. At the needs analysis stage, the researchers interviewed five primary school science teachers in Tawau, Sabah. The interviews were conducted from $5-7$ September 2020 at the primary teacher's room to gain a picture on inculcating entrepreneurial science thinking through the teaching and learning process. All the teachers responded that they received little exposure to the concept of entrepreneurial science and its teaching process because they had no guide or teaching and learning module that they could refer to in relation to applying entrepreneurial science thinking in primary school. Via these interviews, the researchers also realised that these teachers had never undergone any course or training related to entrepreneurial science thinking.

In the analysis of students and context, the criteria were adapted from Carlton et al. (2000) that focused on students' low achievement level, student's prior knowledge about Physical Science and Technology and Sustainable Life themes, sketching skills, creation skills and peer pressure. 30 respondents were chosen for their feedback on this analysis. The analysis showed that students were unanimous in their opinions on all the aspects except for the aspect of prior knowledge about Physical Science and Technology and Sustainable Life themes which 
Jamilah AHMAD, Nyet Moi SIEW. An entrepreneurial science thinking module based on the socioscientific issues approach with thinking wheel map for primary school students in STEM education

they considered they were weak in. Therefore, the teaching process in SIA-TM module was adapted to the fifth-graders' level and needs as best as possible.

\section{Design and Development of SIA-TM Module}

The SIA-TM Module was developed by adapting the socioscientific issues approach that introduces social issues to students which helps them to study the social and scientific components of those issues, as well as encourage them to generate solutions that are based on societal values. To help the students solve socioscientific issues given to them, the thinking wheel map was provided as a thinking tool. The socioscientific issues approach and thinking wheel map were integrated through the Swartz and Parks' (1994) integrated thinking model.

The module has six STEM teaching and learning activities that covers Physical Science and Technology and Sustainable Life themes as found in the latest edition of the Fifth Grade Science Curriculum and Assessment Standard Documents (Curriculum Development Division, 2019). Every activity was allocated 180 minutes. However, this time suggestion for the activity implementation can be customised according to the TL in school as this module can be executed outside TL hours.

Furthermore, the SIA-TM module was also designed to increase students' entrepreneurial science thinking towards STEM via five stages, that are (i) observation (planned and purposeful observation), (ii) new ideas (create ideas by finding uniqueness or strengths), (iii) innovation (select several ideas that can be modified or improved and evaluate those ideas), (iv) creativity (strengthen and improve ideas with focus) and (v) value (ensure that the idea or product created is meaningful to society).

In the observation stage, students were instructed to make planned and purposeful observation. Students were provided with stimulus pictures that showcased the product designs nowadays. Then, students were asked to make observations to garner information on the building materials, design, and product characteristics.

Next, students were tasked at thinking ideas to look for uniqueness and strengths. This stage encouraged students to search for the uniqueness and strengths of the building materials, design, and product characteristics in the product they had observed.

The innovative stage refers to the students' activity of selecting several ideas that can be modified or improved and observe those ideas. The selection of ideas that can be improved helped the students to create a product design in the future. Students then had to evaluate those ideas by stating their reasons for choosing them.

As for the creative stage, this activity is to strengthen and increase ideas in a focused manner based on the ideas that were chosen previously. Students upgraded their ideas by making sketches, labelling, and building the product design model. Next, students had to determine the name of the product, its offer price and target group of buyers.

Lastly, the value stage was for the students to ensure that their ideas or product was useful to society. Students stated the benefits of the product to society. They could state the product's strengths in terms of its cost saving qualities, product functions and properties as well as ethics involved in the creation of the product. This was to inculcate values such as love for the environment and the practice of using sustainable materials in creating a product for society. The students then had to present their creations in class and explain the benefits of their products.

All these stages were carried out in stage according to the thinking wheel map stage. These five stages involved different student activities. To gain maximum effect, the activities in this module were executed in groups to ensure the exchange of ideas and search of creative and innovative solutions. In this module's implementation, the teachers' instructions and guidance was needed. Table 1 shows the integration of the socioscientific issues approach and thinking wheel map in increasing the effects of entrepreneurial science thinking learning module. 
Jamilah AHMAD, Nyet Moi SIEW. An entrepreneurial science thinking module based on the socioscientific issues approach with thinking wheel map for primary school students in STEM education

OF EDUCATION

IN THE $21^{\text {st }}$ CENTURY Vol. 80, No. 1,2022

Table 1

Integration of SIA Approach and TM in the Entrepreneurial Science Thinking TL Module

\begin{tabular}{|c|c|c|}
\hline $\begin{array}{l}\text { Socioscientific Issues } \\
\text { Approach } \\
\text { (SIA) }\end{array}$ & $\begin{array}{l}\text { Thinking Wheel Map } \\
\text { (TM) }\end{array}$ & $\begin{array}{l}\text { Integration of SIA and TM in the } \\
\text { Entrepreneurial Science Thinking TL } \\
\text { Module }\end{array}$ \\
\hline $\begin{array}{l}\text { Phase } 1 \\
\text { Students discover or are } \\
\text { introduced with an issue }\end{array}$ & $\begin{array}{l}\text { First Stage - Observation } \\
\text { Planned a purposeful observation }\end{array}$ & $\begin{array}{l}\text { Introduction } \\
\text { Teacher introduces a socioscientific issue to } \\
\text { students and instructs students to make an } \\
\text { observation towards an issue in the first stage } \\
\text { of TM. }\end{array}$ \\
\hline \multirow{2}{*}{$\begin{array}{l}\text { Phase } 2 \\
\text { Students study the social and } \\
\text { scientific components related } \\
\text { to issues in the first phase. }\end{array}$} & $\begin{array}{l}\text { Second Stage - New Ideas } \\
\text { Create ideas by looking for } \\
\text { uniqueness or strengths in a } \\
\text { product that is observable in } \\
\text { building materials, design, and } \\
\text { products' characteristics. }\end{array}$ & $\begin{array}{l}\text { Think actively } \\
\text { Socioscientific issues and stimulus materials } \\
\text { are used as a guide for students to generate } \\
\text { ideas by finding uniqueness or advantages } \\
\text { through the second stage of TM }\end{array}$ \\
\hline & $\begin{array}{l}\text { Third Stage - Innovation } \\
\text { Selection of several ideas that } \\
\text { can be modified or improved and } \\
\text { evaluate those ideas }\end{array}$ & $\begin{array}{l}\text { Thinking about Thinking } \\
\text { Students are stimulated to choose several } \\
\text { ideas that can be modified or improved and } \\
\text { evaluate those ideas through the third stage of } \\
\text { TM to solve the issues that are presented. }\end{array}$ \\
\hline \multirow{2}{*}{$\begin{array}{l}\text { Phase } 3 \\
\text { Students try to generate a } \\
\text { solution based on societal } \\
\text { values. }\end{array}$} & $\begin{array}{l}\text { Fourth Stage - Creativity } \\
\text { Strengthen and improve the } \\
\text { selected ideas in a focused manner }\end{array}$ & $\begin{array}{l}\text { Consolidation Practice } \\
\text { Students strengthen and improve the ideas } \\
\text { they have chosen in a focused manner in the } \\
\text { fourth stage of TM and sketch their ideas for } \\
\text { the product. }\end{array}$ \\
\hline & $\begin{array}{l}\text { Fifth Stage - Value } \\
\text { Ensure that the idea or product that } \\
\text { is created is meaningful for society. }\end{array}$ & $\begin{array}{l}\text { Applying Thinking } \\
\text { Students state and ensure that the } \\
\text { characteristics of their products is useful to } \\
\text { society and can solve the issues presented in } \\
\text { the fifth stage of TM. }\end{array}$ \\
\hline
\end{tabular}

In designing and developing SIA-TM Module, the STEM element is integrated in the stages of the activity. Appendix shows how the STEM elements are integrated in one of the activities in SIA-TM Module named The New Century Car based on the tasks requested in each stage.

\section{Evaluation Phase}

Taherdoost (2016) stated that a module's content must be verified before it can be applied. The second phase of evaluation is conducted to evaluate the module's reliability, feasibility, and respondents' acceptance. This phase can be conducted after the SIA-TM Module has been shared with the respondent through the process of TL. As suggested by Cohen and Swedlik (2018), a good module usually has a high level of validity and reliability.

A panel of five experts were involved to check the validity of the module's content. These experts were university lecturers, teachers' institute lecturers and primary school science teachers. The entrepreneurial science thinking and STEM experts were a professor from a public university and a lecturer from a teaching institute. The other two experts were teachers with a vast experience in primary school science education.

To measure the module's content validity, an evaluation form was provided to the experts to enable them to provide feedback about the pedagogical content (socioscientific 
issues approach, thinking wheel map and STEM), overall picture of the activity, suitability of each lesson plan, learning standard, overall process of the activity units, integration of the five entrepreneurial science thinking steps, and provide written comments to improve the module. The SIA-TM module was created in Bahasa Melayu to ensure primary school teachers' understanding of the module's content.

A questionnaire was also distributed to the respondents to gather their perceptions about the feasibility of activities proposed in the SIA-TM module. The questionnaire used the 5-point Likert scale with the value 1 (strongly disagree) till 5 (strongly agree). As many as 11 questions were adapted from Rahman (2020) which required students to provide their feedback from the aspect of feelings, benefits from the execution of the five-step entrepreneurial science thinking, the use of the socioscientific issues approach and thinking wheel map.

To establish the reliability of the SIA-TM module, another questionnaire was adapted from Ambo (2019) and given to the respondents. Noah and Ahmad (2005) posit that questionnaires based on activities show a higher reliability index compared to objectives in a module. There were six activities in the SIA-TM module and each activity in the module was evaluated using the Likert Scale starting with the value of 1 (strongly disagree) till 5 (strongly agree). The items that were questioned in each activity were conducted to help respondents cultivate the five constructs of entrepreneurial science thinking that were suitable with the module's learning outcomes. All 30 items were presented in a suitable language level for the primary school level. Both questionnaires were given to 30 fifth graders in the SIA-TM group as soon as the intervention using the module was conducted.

The closing phase (evaluation phase) was done via focus group interviews to gain students' feedback about the SIA-TM module's implementation. They were asked to share their feelings and experiences after using the SIA-TM module and elaborate how the module's use could impact them from the aspect of their entrepreneurial science thinking.

\section{Quasi Experimental Research}

The implementation phase of the experimental research involved the implementation of the teaching and learning (TL) of the SIA-TM module as well as to evaluate its effects in the classroom's session of teaching and learning. In line with this, the pre-test - post-test control group design was employed. A total of 60 students were chosen randomly from two primary schools in the Tawau district and were placed into two groups: treatment group (SIA$\mathrm{TM}, n=30)$, and control group (GC, $n=30$ ). The respondents in the treatment group received the SIA-TM module that comprised of six learning units for 12 weeks from October to December 2020. Each unit required the implementation time of 180 minutes with three missions to be solved; Mission 1: Discussion of socioscientific issues, Mission 2: Discussion of model design, and Mission 3: Presentation of the model design. These three missions could be conducted in three stages according to the suitability of the school's teaching and learning timetable. The respondents in the control group were exposed to the method of designing a conventional design without the use of the socioscientific issues approach and thinking wheel map.

To evaluate the module's effects, the Entrepreneurial Science Thinking Test (ESTT) (Ahmad \& Siew, 2021) that was designed by the researchers was used. This instrument was proven to be valid, reliable and suitable to evaluate fifth-graders' entrepreneurial science thinking. The ESTT consisted of 10 items that required students to answer questions in the form of statements and idea sketches. The questions were constructed based on the five constructs in entrepreneurial science thinking (Buang et al., 2009) which were referred to from the Curriculum and Assessment Standard Document (CASD) Grade Five Science learning contents under the Physical Science and Technology and Sustainable Life themes (Curriculum Development Division, 2014,p. 61-79). The main question asked students to create a handphone design to be 
Jamilah AHMAD, Nyet Moi SIEW. An entrepreneurial science thinking module based on the socioscientific issues approach with thinking wheel map for primary school students in STEM education

PROBLEMS

OF EDUCATION

IN THE $21^{\text {st }}$ CENTURY Vol. 80, No. 1,2022

used by future society. The context of using handphones was chosen because it is contained in the CASD under the Physical Science theme. Students were then provided a stimulus picture and 10 questions that were arranged according to the cluster construct to enable students to organise their answers and get the desired results. The ESTT scoring was done based on the scoring of Ho et al. (2013). Each item that was prepared in this test carried a minimum score of zero and maximum score of three.

\section{Data Analysis}

The descriptive research data were gained through calculating the percentage, mean and standard deviation while the inferential research data were tabulated through the IBM SPSS (version 26) analysis. For this analysis, the level of significance was set to the value of .05. The analysis of qualitative interview data was done using thematic analysis (Braun \& Clarke, 2006) by deriving themes from the interviews about the experiences gained by the $30 \mathrm{fifth}$ graders after using the SIA-TM module. The researchers analysed the interview data thoroughly and gained the pattern linkage from the respondents' experiences and explained the respondents' experiences (Fereday \& Muir-Cochrane, 2006).

\section{Research Results}

\section{Content Validity}

Following the experts' advice, several amendments were made towards the content and activities in the SIA-TM module; i) the design activity according to five constructs was refined to fulfil the entrepreneurial science thinking concept; ii) the lesson plan format of writing was simplified for better clarity; iii) the writing based on learning outcome was specified following the content standard of each unit; iv) the arrangement of activities in the module was changed according to the standard arrangement of contents in the CASD; and v) a simple explanation was inserted for each important concept to increase the readers' understanding. Overall, the expert evaluators agreed that the SIA-TM module was a suitable module to inculcate entrepreneurial science thinking amongst fifth graders.

\section{Reliability}

The reliability of module was determined based on the internal consistency coefficient of Cronbach Alpha. (Cohen et al., 2018). The reliability of the module was assessed after the respondents could master the objectives and could follow the steps in each activity in SIA-TM module at a good level of understanding. Hair et al. (2006) suggested that a Cronbach alpha $\geq$ .7 was acceptable while Sekaran and Bougie (2010) stated that a Cronbach alpha $\geq .8$ usually meant a high reliability. Table 3 shows the Cronbach Alpha values for the learning activities in the SIA-TM module that was gained from the 10-item questionnaire on the 30 respondents. The overall Cronbach Alpha value of SIA-TM module was .82 with a value between .74 to .89 for each unit. This showed that a high reliability level for each activity unit in the module and overall SIA-TM module. 
Jamilah AHMAD, Nyet Moi SIEW. An entrepreneurial science thinking module based on the socioscientific issues approach with thinking wheel map for primary school students in STEM education

\section{Table 3}

Cronbach Alpha Value for Activity Units in the SIA-TM Module

\begin{tabular}{llc}
\hline Unit & Units in the module & Cronbach Alpha Value \\
\hline 1 & New Century Car & .89 \\
2 & Energy Saving Light & .77 \\
3 & My Solar Spectacles & .79 \\
4 & Five Stars Television & .84 \\
5 & My Sustainable Home & .86 \\
6 & Eco-Friendly Food Container & .74 \\
\hline & Total & .82 \\
\hline
\end{tabular}

Students' Perceptions about the Feasibility of SIA-TM Module

Table 4 showcases the students' perceptions about the feasibility of SIA-TM module, and it was collected via the questionnaire given to the respondents. The overall mean of 4.53 showed that the SIA-TM module had high value of acceptance and feasibility. $30 \%$ of the respondents agreed while $63 \%$ strongly agreed with the SIA-TM module's feasibility. The criteria that show a minimum mean of 3.50 shows that the feasibility aspect of the module is acceptable (Junus et al., 2021). However, if the mean level was below 3.50, changes will have to be made because the module's feasibility will be considered unsatisfactory. The research findings between the levels of 4.06 to 4.86 proved that the SIA-TM module was feasible in cultivating entrepreneurial science thinking among fifth graders. 
Jamilah AHMAD, Nyet Moi SIEW. An entrepreneurial science thinking module based on the socioscientific issues approach with thinking wheel map for primary school students in STEM education

IN THE $21^{\text {st }}$ CENTURY Vol. 80 , No. 1,2022
Table 4

Percentage and Mean for Students' Perceptions about the Feasibility of SIA-TM Module

\begin{tabular}{|c|c|c|c|c|c|c|c|}
\hline & \multirow[b]{2}{*}{ Pedagogical feasibility criteria } & \multicolumn{6}{|c|}{ Percentage and mean according to Likert Scale } \\
\hline & & $\begin{array}{l}1 \\
\text { Strongly } \\
\text { Disagree }\end{array}$ & $\begin{array}{l}2 \\
\text { Disagree }\end{array}$ & $\begin{array}{l}3 \\
\text { Neutral }\end{array}$ & $\begin{array}{l}4 \\
\text { Agree }\end{array}$ & $\begin{array}{l}5 \\
\text { Strongly } \\
\text { Agree }\end{array}$ & Mean \\
\hline 1 & $\begin{array}{l}\text { The science learning activities which use } \\
\text { the SIA-TM module stimulates my thinking } \\
\text { to look for solutions for the social issues } \\
\text { brought up. }\end{array}$ & $\begin{array}{l}0 \\
(0)\end{array}$ & $\begin{array}{l}0 \\
(0)\end{array}$ & $\begin{array}{l}1 \\
(3)\end{array}$ & $\begin{array}{l}5 \\
(17)\end{array}$ & $\begin{array}{l}24 \\
(80)\end{array}$ & 4.76 \\
\hline 2 & $\begin{array}{l}\text { The science learning activities which use } \\
\text { the SIA-TM module encourages me to } \\
\text { create many new ideas. }\end{array}$ & $\begin{array}{l}0 \\
(0)\end{array}$ & $\begin{array}{l}0 \\
(0)\end{array}$ & $\begin{array}{l}0 \\
(0)\end{array}$ & $\begin{array}{l}14 \\
(47)\end{array}$ & $\begin{array}{l}16 \\
(53)\end{array}$ & 4.53 \\
\hline 3 & $\begin{array}{l}\text { The science learning activities which use } \\
\text { the SIA-TM module stimulates my mind to } \\
\text { create ideas that can be applied to current } \\
\text { needs. }\end{array}$ & $\begin{array}{l}0 \\
(0)\end{array}$ & $\begin{array}{l}1 \\
(3)\end{array}$ & $\begin{array}{l}2 \\
(7)\end{array}$ & $\begin{array}{l}10 \\
(33)\end{array}$ & $\begin{array}{l}17 \\
(57)\end{array}$ & 4.43 \\
\hline 4 & $\begin{array}{l}\text { The science learning activities which use } \\
\text { the SIA-TM module stimulates my mind to } \\
\text { expand my initial ideas to more interesting } \\
\text { new ideas. }\end{array}$ & $\begin{array}{l}0 \\
(0)\end{array}$ & $\begin{array}{l}1 \\
(3)\end{array}$ & $\begin{array}{l}2 \\
(7)\end{array}$ & $\begin{array}{l}7 \\
(23)\end{array}$ & $\begin{array}{l}20 \\
(67)\end{array}$ & 4.53 \\
\hline 5 & $\begin{array}{l}\text { The science learning activities which use } \\
\text { the SIA-TM module stimulates my mind to } \\
\text { create designs that can benefit society. }\end{array}$ & $\begin{array}{l}0 \\
(0)\end{array}$ & $\begin{array}{l}0 \\
(0)\end{array}$ & $\begin{array}{l}1 \\
(3)\end{array}$ & $\begin{array}{l}14 \\
(47)\end{array}$ & $\begin{array}{l}15 \\
(50)\end{array}$ & 4.47 \\
\hline 6 & $\begin{array}{l}\text { The science learning activities which use } \\
\text { the SIA-TM module increases the quality of } \\
\text { the module design. }\end{array}$ & $\begin{array}{l}0 \\
(0)\end{array}$ & $\begin{array}{l}2 \\
(7)\end{array}$ & $\begin{array}{l}4 \\
(13)\end{array}$ & $\begin{array}{l}14 \\
(47)\end{array}$ & $\begin{array}{l}10 \\
(33)\end{array}$ & 4.06 \\
\hline 7 & $\begin{array}{l}\text { The science learning activities which use } \\
\text { the SIA-TM module increases my science } \\
\text { knowledge. }\end{array}$ & $\begin{array}{l}0 \\
(0)\end{array}$ & $\begin{array}{l}0 \\
(0)\end{array}$ & $\begin{array}{l}0 \\
(0)\end{array}$ & $\begin{array}{l}4 \\
(13)\end{array}$ & $\begin{array}{l}26 \\
(87)\end{array}$ & 4.86 \\
\hline 8 & $\begin{array}{l}\text { The science learning activities which } \\
\text { use the SIA-TM module increases } \\
\text { entrepreneurship orientation in me. }\end{array}$ & $\begin{array}{l}0 \\
(0)\end{array}$ & $\begin{array}{l}2 \\
(7)\end{array}$ & $\begin{array}{l}2 \\
(7)\end{array}$ & $\begin{array}{l}13 \\
(43)\end{array}$ & $\begin{array}{l}13 \\
(43)\end{array}$ & 4.23 \\
\hline 9 & $\begin{array}{l}\text { I enjoyed learning Science using the SIA- } \\
\text { TM module. }\end{array}$ & $\begin{array}{l}0 \\
(0)\end{array}$ & $\begin{array}{l}1 \\
(3)\end{array}$ & $\begin{array}{l}2 \\
(7)\end{array}$ & $\begin{array}{l}8 \\
(27)\end{array}$ & $\begin{array}{l}19 \\
(63)\end{array}$ & 4.50 \\
\hline 10 & $\begin{array}{l}\text { My curiosity in STEM education has } \\
\text { increased after learning Science using the } \\
\text { SIA-TM module. }\end{array}$ & $\begin{array}{l}0 \\
(0)\end{array}$ & $\begin{array}{l}1 \\
(3)\end{array}$ & $\begin{array}{l}2 \\
(7)\end{array}$ & $\begin{array}{l}6 \\
(20)\end{array}$ & $\begin{array}{l}21 \\
(70)\end{array}$ & 4.57 \\
\hline 11 & $\begin{array}{l}\text { I am interested now to follow learning } \\
\text { activities using the SIA-TM module in the } \\
\text { future. }\end{array}$ & $\begin{array}{l}0 \\
(0)\end{array}$ & $\begin{array}{l}0 \\
(0)\end{array}$ & $\begin{array}{l}0 \\
(0)\end{array}$ & $\begin{array}{l}5 \\
(17)\end{array}$ & $\begin{array}{l}25 \\
(83)\end{array}$ & 4.83 \\
\hline & Total & $\begin{array}{l}0 \\
(0)\end{array}$ & $\begin{array}{l}8 \\
(2)\end{array}$ & $\begin{array}{l}16 \\
(5)\end{array}$ & $\begin{array}{l}100 \\
(30)\end{array}$ & $\begin{array}{l}206 \\
(63)\end{array}$ & 4.53 \\
\hline
\end{tabular}


Jamilah AHMAD, Nyet Moi SIEW. An entrepreneurial science thinking module based on the socioscientific issues approach with thinking wheel map for primary school students in STEM education

PROBLEMS

OF EDUCATION

IN THE $21^{\text {st }}$ CENTURY

Vol. 80 , No. 1,2022

Effects of the SIA-TM Module
41

Paired Sample t-Test

The paired sample $t$-test was executed to determine whether there was any significant difference between the pre-test and the post-test mean scores for the SIA-TM group from the aspect of the five constructs of entrepreneurial science thinking. Research results in Table 5 show that the post-test mean score was significantly different from the pre-test mean score from the aspect of these constructs: Observation, New Ideas, Innovation, Creativity and Value. Each value was $(t(29)=-20.707, p<.05 ; t(29)=-23.404, p<.05 ; t(29)=-28.580, p<.05$; $t(29)=-25.284, p<.05 ; t(29)=-24.814, p<.05)$. These findings show that the SIA-TM group performed better in the post-test compared to the pre-test in the five constructs of entrepreneurial science thinking.

The findings of paired sample t-test sample for the control group (CG) (Table 5) also showed a higher significant difference for the post-test compared to the pre-test from the aspect of the Observation, New Ideas, Innovation, Creativity and Value constructs with each value at $(t(29)=-7.990, p<.05 ; t(29)=-7.999, p<.05 ; t(29)=-5.530, p<.05 ; t(29)=-6.998, p<.05$; $t(29)=-7.940, p<.05)$. These findings also prove that the control group performed better in the post-test compared to the pre-test in the five constructs of entrepreneurial science thinking.

Table 5

Results of Paired Sample t-test Analysis

\begin{tabular}{|c|c|c|c|c|c|c|c|}
\hline \multirow{2}{*}{ Construct } & \multirow{2}{*}{ Group } & Pre-Test & Post-Test & Difference & \multirow[t]{2}{*}{$t$} & \multirow[t]{2}{*}{$d f$} & \multirow[t]{2}{*}{$p$} \\
\hline & & \multicolumn{3}{|c|}{ Mean (Standard Deviation) } & & & \\
\hline \multirow[t]{2}{*}{ Observation } & SIA-TM & $2.37(.669)$ & $4.93(.640)$ & $-2.567(.679)$ & -20.707 & 29 & $<.05$ \\
\hline & CG & $2.30(.596)$ & $3.57(.568)$ & $-1.267(.868)$ & -7.990 & 29 & $<.05$ \\
\hline \multirow[t]{2}{*}{ New Idea } & SIA-TM & $2.23(.679)$ & $4.97(.615)$ & $-2.733(.640)$ & -23.404 & 29 & $<.05$ \\
\hline & CG & $2.27(.691)$ & $3.40(.894)$ & $-1.133(.776)$ & -7.999 & 29 & $<.05$ \\
\hline \multirow[t]{2}{*}{ Innovation } & SIA-TM & $2.47(.819)$ & $5.07(.868)$ & $-2.600(.498)$ & -28.580 & 29 & $<.05$ \\
\hline & CG & $2.50(.731)$ & $3.33(.661)$ & $-.833(.699)$ & -6.530 & 29 & $<.05$ \\
\hline \multirow[t]{2}{*}{ Creativity } & SIA-TM & $2.57(.774)$ & $5.17(.699)$ & $-2.600(.563)$ & -25.284 & 29 & $<.05$ \\
\hline & CG & $2.60(.621)$ & $3.63(.765)$ & $-1.033(.809)$ & -6.998 & 29 & $<.05$ \\
\hline \multirow[t]{2}{*}{ Value } & SIA-TM & $2.40 .675)$ & $5.10(.712)$ & $-2.700(.596)$ & -24.814 & 29 & $<.05$ \\
\hline & CG & $2.40(.675)$ & $3.50(.682)$ & $-1.100(.759)$ & -7.940 & 29 & $<.05$ \\
\hline
\end{tabular}

Note: Significance level at $p=.05$

\section{Independent Sample T-Test}

Independent sample $t$-test was conducted to compare the pre-test mean score for the five constructs between the SIA-TM and CG. Analysis results (Table 6) indicated that there were no significant differences between the pre-test mean scores between SIA-TM and CG in the Observation, New Ideas, Innovation, Creativity and Value constructs with each construct's value at $(t(58)=.408, p>.05 ; t(58)=-.188, p>.05 ; t(58)=-.166, p>.05 ; t(58)=-.184, p>$ $.05 ; t(58)=0.00, p>.05)$.

Gay and Airasian (2003) stated that if there were no significant differences for the mean scores between the two pre-tests, then the $t$-test could be conducted on the post-test mean score. 
Jamilah AHMAD, Nyet Moi SIEW. An entrepreneurial science thinking module based on the socioscientific issues approach with thinking wheel map for primary school students in STEM education

PROBLEMS

OF EDUCATION

IN THE $21^{\text {st }}$ CENTURY Vol. 80 , No. 1,2022

Thus, the independent sample $t$-test was carried out to compare the SIA-TM and the CG mean scores in the five constructs of entrepreneurial science thinking. The analytical results show that the respondents in the SIA-TM group had a significant higher post-test mean score compared to the control group from the aspect of Observation, New Ideas, Innovation, Creativity and Value constructs with each value at $(t(58)=8.748, p<.05 ; t(58)=7.906, p<.05 ; t(8)=8.700, p<.05$; $t(58)=8.106, p<.05 ; t(58)=8.887, p<.05)$. These results proved that there was a significant difference in the post-test for students from the SIA-TM group compared to those in the CG in the five constructs of entrepreneurial science thinking.

Table 6

Results of the Independent Sample t-test Analysis

\begin{tabular}{llllllll}
\hline Construct & Test & $\begin{array}{l}\text { SIA-TM Group } \\
\text { Mean (SP) }\end{array}$ & $\begin{array}{l}\text { Control Group } \\
\text { Mean (SP) }\end{array}$ & $\begin{array}{l}\text { Group } \\
\text { Difference }\end{array}$ & $\boldsymbol{t}$ & df & $\boldsymbol{P}$ \\
\hline Observation & Pre & $2.37(.669)$ & $2.30(.596)$ & $.067(.164)$ & .408 & 58 & $>.05$ \\
\hline & Post & $4.93(.640)$ & $3.57(.568)$ & $1.367(.156)$ & 8.748 & 58 & $<.05$ \\
\hline New Ideas & Pre & $2.23(.679)$ & $2.27(.691)$ & $-.033(.177)$ & -.188 & 58 & $>.05$ \\
\hline \multirow{2}{*}{ Innovation } & Pre & $2.47(.819)$ & $2.50(.731)$ & $-.033(.200)$ & -.166 & 58 & $>.05$ \\
\hline \multirow{2}{*}{ Creativity } & Pre & $2.97(.615)$ & $3.40(.894)$ & $1.567(.198)$ & 7.906 & 58 & $<.05$ \\
\hline \multirow{2}{*}{ Value } & Post & $5.07(.868)$ & $3.33(.661)$ & $1.733(.199)$ & 8.700 & 58 & $<.05$ \\
\hline & Pre & $2.40(.675)$ & $2.40(.675)$ & $0.00(.174)$ & 0.00 & 58 & $>.05$ \\
\hline & Post & $5.10(.712)$ & $3.50(.682)$ & $1.600(.180)$ & 8.887 & 58 & $<.05$ \\
\hline
\end{tabular}

Note: Significance level at $p=.05$

\section{Interviews with the Focus Group}

Several themes were identified based on the respondents' views in the focus group interviews towards the implementation of the SIA-TM teaching and learning module. A total of three focus groups were involved with each consisting of five respondents. The abbreviation used for the analysis was ' $G$ ' represents Group. The findings are as follows:

Arrangement of ideas and expansion of new ideas. The use of the SIA-TM module helped students to arrange their ideas in a more organised way and expanded their new ideas.

"...when we were asked to write in the wheel... we were thinking why we have to use the wheel... can't we just create the product... but when we did it... the ideas came one by one... then (we realised) the importance of the wheel... If there was no wheel... it would be difficult...we wouldn't know how to arrange ideas... this map gave a new opportunity to us to open our ideas..." (G2)

"...before we created an object... we were very nervous... but when we used the map... it really helped... we felt it was easy to create... the wheel map has stages... so this really helps... till the fourth stage, we felt this task was actually easy...ideas could be arranged easily... we could create a product more systematically..." (G3)

“... any ideas that came to our minds and ideas that we thought would not be forgotten..." (G1) 
Jamilah AHMAD, Nyet Moi SIEW. An entrepreneurial science thinking module based on the socioscientific issues approach with thinking wheel map for primary school students in STEM education

Increase in STEM knowledge. Students also stated that the SIA-TM module increased their Vol. 80 , No. 1,2022 STEM knowledge.

“...We were really excited to learn STEM with this method... socioscientific issues really helped us to produce eco -friendly products..." (G1)

“...this module is really new for us... if we don't join this learning experience ... we don't even know that our environment is already bad polluted... it's like the polystyrene issue ... we really don't think why can be so much... that's why our team produce food containers that do not pollute the environment ... we use banana leaves that are easily biodegradable..." (G2)

"...At first, we asked ourselves what STEM is. After writing in the wheel map, then we could understand... because we had to produce products that used the knowledge of science, technology, engineering and mathematics... when producing a car... we have to sketch the car... build it according to the appropriate material... calculate the speed of the car... set the price of the car and we use water as car fuel to produce hydrogen which is safer for nature..." (G3)

Excitement when creating a prototype. Students expressed their excitement and thrill when creating their prototypes.

"... we created a car that used water because the use of fossil fuels is not good for the environment... we felt this was very fun because the map helped us to create the car... We arranged our ideas one by one until the car was created..." (G2)

“...We're impressed with ourselves ... our group did not expect to create a product for the future... we were really ... really happy..." (G3)

Inculcates the value of helping the society in the future. The use of the innovative SIA-TM module proved to help students to cultivate a feeling of responsibility to solve universal issues to help future society.

“...at first, we were given issues to discuss... we also did not know that our world is facing the issues that our teacher showed us... so on the wheel map, we wrote the issues that we discussed... then we wrote ideas to create a product... that helps the society in the future..." (G1)

"... at first... we were scared that this project would not work out... but when it was done as a group... we could create a product that we wanted for the future community..." (G2)

Increase of curiosity. The students' curiosity was also increased through this innovative SIATM module.

“... during the creation of our product... we asked each other questions in our group... because we want to know what would happen if we did something like this... we wanted to know the outcome..." (G3)

“... actually... we were afraid that our plan would not work out... but after writing ideas on the wheel map... we did what was planned... we were impatient to know what would happen next..." (G1)

Encourages teamwork in a group. The value of teamwork and unity in a group could be brought out through the innovative SIA-TM module.

“... the wheel map helps us to collaborate in creating our group project...” (G1) 
Jamilah AHMAD, Nyet Moi SIEW. An entrepreneurial science thinking module based on the socioscientific issues approach with thinking wheel map for primary school students in STEM education

PROBLEMS

OF EDUCATION

IN THE $21^{\text {st }}$ CENTURY Vol. 80 , No. 1,2022

44
".. at first... we were scared that this project would not work. But after doing it as a group... we managed to produce our product for the future society... for example... when making the ecofriendly food containers... we discussed together how to produce food containers from more sustainable banana leaves..." (G2)

“...we felt nervous because we were scared to get it wrong... but after doing it... we felt happy... all of us did it together... the wheel was done together... we discussed together to get ideas... finally... we succeeded..." (G3)

\section{Discussion}

This research was carried out to develop a SIA-TM module that is more geared towards meeting the needs of students facing the global challenges of twenty first century. To ensure its applicability in primary schools, assessments on its validity, reliability, feasibility, and effect were analysed. The SIA-TM module was developed based on a clear and detailed theoretical framework which integrated the socioscientific issues approach and the thinking wheel map using the Swartz and Park's model of integration to measure the effect it had on the five constructs of the entrepreneurial science thinking.

Overall, the results have proven that the SIA-TM module had a valid and reliable content which is feasible in increasing fifth-graders' entrepreneurial science thinking. The analysis on the module's content validity proves that the SIA-TM module was well received by the panel of five expert evaluators. It also underwent several improvements towards a few aspects in the module. The reliability analysis showed that the SIA-TM module was within an acceptable range based on Cronbach's Alpha value.

The paired sample $t$-test showed that fifth graders in both the SIA-TM and CG groups displayed a significant better performance in the five constructs of entrepreneurial science thinking in the post-test compared to the pre-test. Nevertheless, the fifth graders that were taught in the SIA-TM group had a higher improvement score compared to their peers who were taught in the control group. This means that the chance to learn under the teaching and learning of SIA-TM module can have a better effect on the students' entrepreneurial science thinking. For the independent sample $t$-test, results showed that the use of the SIA-TM teaching and learning module could increase entrepreneurial science thinking more effectively compared to control group.

Exposure to the socioscientific issues in the SIA-TM module enabled students to make connections between socioscientific issues and their experiences. The discussion of socioscientific issues encourages the beginning of observation and investigation of a phenomena or situation (Darmaji et al., 2019; Kohlhauf et al., 2011). The argument made for the socioscientific issues together with the observation analysis will encourage students to observe a trend and predict situations that have not occurred or have not been witnessed (Syukri et al., 2013). This strengthens the point that the socioscientific issues approach aids students in providing an initial overview of the product to be created.

Furthermore, exposure to the socioscientific issues approach through the SIA-TM module opens a space for students to expand their knowledge on issues (Khishfe et al., 2017). In this approach, socioscientific issues are put forward in each activity unit, and presented together with examples and pictures which showed the socioscientific situations that are occurring now. The introduction to the socioscientific issues enables students to make observations based on current situations such as critical pollution. The information brought forward by these issues provides students with an input to create products that could possibly solve those socioscientific issues.

Additionally, the increase of the students' mean score who followed the SIA-TM module compared to those in the CG could be explained through the detailed step of socioscientific 
issues approach (Topçu et al., 2018). In the first phase of the socioscientific issues approach

that introduced students to the focus of the issues, students received guidance to make early observations about the topic discussed in the issue. Then, the second phase involved making connections between scientific ideas and society's awareness, increasing observational skills among students (by asking questions in groups), connecting experiences to new discoveries, gaining new knowledge, and procuring connections between the events. The use of the socioscientific issues approach aided by the thinking wheel map increases the students' entrepreneurial science thinking skills. This is because the discussion of the issues which are expressed in the thinking wheel map can provide a clearer understanding to the students about what needs to be observed and look for answers for the issues (Mutvei et al., 2017).

The integration of the socioscientific issues approach with the thinking wheel map also encourages students to note down ideas systematically (Bengston, 2016). Any ideas that are thought of as logical and suitable with the observation, new ideas, innovation, creativity, and value constructs about the product are entered into the thinking map's stages. This facilitates students' endeavours because the stage in the wheel helps them to collect ideas speedily and systematically. The effect of this integration is proven to aid students to master the five constructs of the entrepreneurial science thinking since the thinking wheel map is easy to understand and stimulate students' systematic thinking during the brainstorming session in groups (Krueger, 2005).

The increased degree of students' entrepreneurial science thinking in the five constructs for the SIA-TM method compared to the CG method was clearly aided by the integration of the systematic SIA and TM. Researchers (Kinslow \& Sadler, 2018; Sadler et al., 2017; Topçu et al., 2018) also supported the use of SIA with TM as it helps to increase the students' scientific knowledge when they explore the given socioscienctific issues. The debate of socioscientific issues leads to the debate of ideas that can expand scientific knowledge and its implication on society to ensure the students make the best decision. Following this, SIA drives students to make precise decisions in choosing the best ideas to be expanded in their product creations (Sadler \& Zeidler, 2005; Zeidler, 2016; Zeidler \& Nichols, 2009) and systematically expresses all this in the thinking wheel map (Bengston, 2016).

The socioscientific issues approach aided by the thinking wheel map also trains students to make decisions about social issues that involve a moral implication in a scientific context (Zeidler et al., 2003; Zeidler et al., 2005). Prior studies (Driver et al., 2000; Sadler, 2004) also agree that socioscientific issues enabled students to study and connect science with daily life and communities. This is in line with the objective of implementing entrepreneurial science thinking where students are capable of connecting science with society to create products that are compatible with societal needs and solve socioscientific issues that arise in society.

Moreover, the interview findings also proved that the use of SIA-TM module assisted students to organise ideas and expand new ideas more effectively as well as increased their STEM knowledge. Students who underwent learning through the SIA-TM module were also discovered to have enjoyed making the prototype and were more curious throughout the SIATM learning experience. In fact, the students also developed an awareness and responsible attitude towards their future community and teamwork in their respective teams.

In general, this study differs from past research studies in several ways. Syukri et al. (2013) who developed the module using the Entrepreneurial Science Learning Model found students' performance and enthusiasm in science learning improved, so did students' attitudes and opinions about entrepreneurship. However, Syukri et al.'s study was not intended to investigate the effects of the module on students' entrepreneurial science thinking. Mat Nawi and Tuan Soh (2018) performed research on the application of entrepreneurial science thinking. The study, on the other hand, investigated the science teachers' awareness and level of entrepreneurial scientific thinking in terms of enhancing students' creativity and innovation. Ishak et al. (2014) 
Jamilah AHMAD, Nyet Moi SIEW. An entrepreneurial science thinking module based on the socioscientific issues approach with thinking wheel map for primary school students in STEM education

PROBLEMS

OF EDUCATION

IN THE $21^{\text {st }}$ CENTURY Vol. 80, No. 1,2022

investigated the readiness of science teachers from MARA Junior Science College to integrate entrepreneurial thinking into their teaching process. This research, once again, focuses on EST teaching preparation among teachers rather than on students. In comparison, very limited research has been conducted to date which concentrates on the development of modules to foster entrepreneurial science thinking among learners. The employment of a socioscientific issue approach with the use of thinking wheel map distinguishes this study.

\section{Conclusions and Implications}

The research demonstrated that the principles of using ADDIE instructional design model by integrating explicitly the constructivist learning theory, the socioscientific issues approach and thinking wheel map using Swartz and Park's integration model offer the potential for developing a SIA-TM teaching and learning module which is valid, reliable, feasible and effective in fostering entrepreneurial science thinking among fifth graders in STEM education. Students not only got to increase their level of entrepreneurial science thinking, but also improved their STEM knowledge, expansion of their ideas, sense of enjoyment and sense of teamwork. Nevertheless, this research involved only 60 Grade Five students and may not be representative of the primary school students' population as a whole. Future research will therefore need to be carried out with a larger sample size and multi-age group to assess extensively the learning effects of SIA-TM teaching and learning module on entrepreneurial science thinking.

The empirically proven ADDIE instructional design model with an integrated application of the socioscientific issues approach and thinking wheel map can be further upgraded or improved to serve as a reference model for educators who are interested in developing a learning module which fosters the science entrepreneurial thinking of different level of students. The integrated model is also a contribution to support the goal of education in many countries, that is to develop and produce globally competitive students who think critically, creatively, innovatively, and inhibit high entrepreneurial values.

\section{Acknowledgement}

The researchers would like to express their sincere gratitude to University Malaysia Sabah, Sabah, Malaysia for supporting this research under Grant No. SDN0005-2019.

\section{Declaration of Interest}

The authors declare no competing interest.

\section{References}

Ahmad, J., \& Siew, N. M. (2021). Development of a children entrepreneurial science thinking test for STEM education. Journal of Baltic Science Education, 20(4), 528 545. https://doi.org/10.33225/jbse/21.20.528

Ambo, N. (2019). Kesan pembelajaran sains berasaskan projek dan pendekatan STEM terhadap lima dimensi sifat kreativiti saintifik murid tahun lima [The effects of project-based science learning and STEM approaches on the five dimensions of scientific creativity of fifth graders]. Doctoral Thesis, Universiti Malaysia Sabah, Kota Kinabalu, Malaysia.

Bacigalupo, M., Kampylis, P., Punie, Y., \& Van den Brande, G. (2016). EntreComp: The entrepreneurship competence framework. Publications Office of the European Union. https://doi.org/10.2791/593884

Bengston, D. N. (2016). The futures wheel: A method for exploring the implications of social-ecological change. Society and Natural Resources, 29(3), 374-379. https://doi.org/10.1080/08941920.2015.1054980 
Jamilah AHMAD, Nyet Moi SIEW. An entrepreneurial science thinking module based on the socioscientific issues approach with thinking wheel map for primary school students in STEM education

PROBLEMS

OF EDUCATION

IN THE $21^{\text {st }}$ CENTURY

Vol. 80 , No. 1,2022

Birmingham, D., \& Barton, A. C. (2014). Putting on a green carnival: Youth taking educated action on socioscientific issues. Journal of Research in Science Teaching, 51(3), 286314. https://doi.org/10.1002/tea.21127

Bloom, B. S. (1956). Taxonomy of educational objectives, Handbook 1: Cognitive domain (2nd Ed.). David McKay Company. https://doi.org/10.1300/J104v03n01_03

Bujang, M. A., Omar, E. D., \& Baharom, N. A. (2018). A review on sample size determination for Cronbach's alpha test: A simple guide for researchers. Malaysian Journal of Medical Sciences, 25(6), 85-99. https://doi.org/10. 21315/mjms2018.25.6.9

Branch, R. M. (2010). Instructional design: The ADDIE approach. Springer. https://doi.org/10.4135/9781412958806.n258

Braun, V., \& Clarke, V. (2006). Using thematic analysis in psychology. Qualitative Research in Psychology, 3(77), 77-101.

Carlton, D. J., Kicklighter, J. R., Jonnalagadda, S. S., \& Shoffner, M. B. (2000). Design development and formative evaluation for adult program. Journal of the American Dietetic Association, 100(5), $555-563$.

Chua, Y. P. (2011). Kaedah dan statistik penyelidikan: Kaedah penyelidikan [Methods and research statistics: Research methods]. Mcgraw-Hill Education.

Curriculum Department Division. (2019). Dokumen standard kurikulum dan pentaksiran Sains Tahun Lima [Year Five science curriculum and assessment standard document]. Ministry of Education Malaysia.

Cohen, L., Manion, L., \& Morrison, K. (2018). Research methods in education. Routledge.

Cohen, R. J., \& Swedlik, M. E. 2018. Psychological testing and assessment: An introduction to tests and measurement. Guidebook for Clinical Psychology Interns (9th ed.). McGraw-Hill Education.

Conroy, R. (2021). The RCSI Sample size handbook: A rough guide. Beaumont Hospital Ethics Committee. https://www.beaumontethics.ie/docs/application/samplesize2021.pdf

Darmaji, Kurniawan, D. A., \& Irdianti. (2019). Physics education students' science process skills. International Journal of Evaluation and Research in Education, 8(2), 293-298. https://doi.org/10.11591/ijere.v8i2.28646

Driver, R., Newton, P., \& Osborne, J. (2000). Establishing the norms of scientific argumentation in classrooms. Science Education, 84(3), 287. https://doi.org/10.1002/(SICI)1098237X(200005)84:3\%3C287::AID-SCE1\%3E3.0.CO;2-A

Fereday, J., \& Muir-Cochrane, E. (2006). Demonstrating rigor using thematic analysis: A hybrid approach of inductive and deductive coding and theme Development. Interdisciplinary Journal of Qualitative Methods, 5(1), 80-92. https://doi.org/10.1177/160940690600500107

Gay, L. R., \& Airasian, P. W. (2003). Educational research: Competencies or analysis and applications. Prentice Hall.

Glenn, J. (1972). Futurizing teaching vs. futures courses. Social Science Record, 9(3), 26-29.

Hair, J. F., Black, W. C., Babin, B. J., Anderson, R. E., \& Tatham, R. L. (2006). Multivariate data analysis (6th Ed.). Prentice Hall.

Ho, H.-C., Wang, C.-C., \& Cheng, Y.-Y. (2013). Analysis of the scientific imagination process. Thinking Skills and Creativity, 10, 68-78.

Ishak, Z., Buang, N. A., \& Halim, L. (2014). Ciri-ciri dan tahap pemikiran sains keusahawanan: Kesediaan integrasi pemikiran keusahawanan dalam proses pengajaran guru-guru sains di MRSM [Characteristics and level of entrepreneurial science thinking: Willingness to integrate entrepreneurial thinking in the teaching process of science teachers at MRSM]. Jurnal Kepimpinan Pendidikan [Journal of Educational Leadership], 1(1), 53-64.

Jones, M. G., \& Brader-Araje, L. (2002). The impact of constructivism on education: Language, discourse, and meaning. American Communication Journal, 5(3), 1-10.

Junus, I. S., Santoso, H. B., Isal, R. Y. K., \& Utomo, A. Y. (2021). Usability evaluation of the student centered e-learning environment. International Review of Research in Open and Distributed Learning, 16(4), 62-82. https://doi.org/https://doi.org/10.19173/irrodl.v16i4.2175

Karlsson, C., Rickardsson, J., \& Wincent, J. (2021). Diversity, innovation, and entrepreneurship: Where are we and where should we go in future studies? Small Business Economics, 56(2), 759-772. https://doi.org/10.1007/s11187-019-00267-1 
Jamilah AHMAD, Nyet Moi SIEW. An entrepreneurial science thinking module based on the socioscientific issues approach with thinking wheel map for primary school students in STEM education

PROBLEMS

OF EDUCATION IN THE $21^{\text {st }}$ CENTURY Vol. 80 , No. 1,2022

Khishfe, R., Alshaya, F. S., BouJaoude, S., Mansour, N., \& Alrudiyan, K. I. (2017). Students' understandings of nature of science and their arguments in the context of four socio-scientific issues. International Journal of Science Education, 39(3), 299-334. https://doi.org/10.1080/09500693.2017.1280741

Kinslow, A. T., \& Sadler, T. D. (2018). Making science relevant: Using socio-scientific issues to foster critical thinking. The Science Teacher, 86(1), 40-45.

Mat Nawi, S. S., \& Tuan Soh, T. M. (2018). Penerapan pemikiran sains keusahawanan dalam proses pengajaran Sains [The application of entrepreneurial science thinking in the Science teaching process]. Prosiding Seminar Kebangsaan Majlis Dekan Pendidikan Universiti Awam [Proceedings of the National Seminar of the Council of Deans of Public University Education] (pp. 7-8). https://www.unisza.edu.my/medc2018

Mutvei, A., Lönn, M., \& Mattsson, J.-E. (2017, August 21-25). Development of observation skills in science education for enhanced understanding [Paper Presentation]. European Science Education Research Association (ESERA) Conference, Dublin, Ireland.

Nam, Y., \& Chen, Y. C. (2017). Promoting argumentative practice in socio-scientific issues through a science inquiry activity. Eurasia Journal of Mathematics, Science and Technology Education, 13(7), 3431-3461. https://doi.org/10.12973/eurasia.2017.00737a

Noah, S.M., \& Ahmad, J. (2005). Module development: How to develop practice module and academic module. University Putra Malaysia.

Buang, N. A., Halim, L., \& Subahan, T. M. M. (2009). Understanding the thinking of scientists entrepreneurs: Implications for science education in Malaysia. Journal of Turkish Science Education, 6(2), 3-11.

Owens, D. C., Sadler, T. D., \& Zeidler, D. L. (2017). Controversial issues in the science classroom. Phi Delta Kappan, 99(4), 45-49. https://doi.org/10.1177/0031721717745544

Pascual-Leone, J., \& Johnson, J. (2005). A dialectical constructivist view of developmental intelligence. Handbook of Understanding and Measuring Intelligence, 177-201.

Piaget, J. (1976). Piaget's theory. In Piaget and His School (pp. 11-23). https://doi.org/10.1007/978-3-642-46323-5_2

Rahman, M.S.A. (2020). Pendekatan berasaskan sosio-saintifik berbantukan peta pemikiran masa hadapan terhadap lima konstruk pemikiran masa hadapan pelajar [The socio-scientific-based approach helped with future thinking map on the five constructs of students' future thinking]. Doctoral Thesis, Universiti Malaysia Sabah, Kota Kinabalu, Malaysia.

Saavedra, A. R., \& Opfer, V. D. (2012). Learning 21st-century skills requires 21st-century teaching. Phi Delta Kappan, 94(2), 8-13. https://doi.org/10.1177/003172171209400203

Sadler, T. D. (2004). Informal reasoning regarding socioscientific issues: A critical review of research. Journal of Research in Science Teaching, 41(5), 513-536. https://doi.org/10.1002/tea.20009

Sadler, T. D., \& Zeidler, D. L. (2005). The significance of content knowledge for informal reasoning regarding socioscientific issues: Applying genetics knowledge to genetic engineering issues. Science Education, 89(1), 71-93. https://doi.org/10.1002/sce.20023

Sadler, T. D., Foulk, J. A., \& Friedrichsen, P. J. (2017). Evolution of a module for socio-scientific issue teaching and learning. International Journal of Education in Mathematics Science and Technology, $5(2), 75-87$.

Sekaran, U., \& Bougie, R. (2010). Research methods for business: A skill building approach (5th ed.). John Willey \& Sons.

Sjøberg, S. (2007). Contructivism and learning. In International Encyclopaedia of Education (3rd ed.). Elsevier. https://doi.org/10.1134/S1061933X16060144

Swartz, R. J., \& Parks, S. (1994). Infusing the teaching of critical and creative thinking into content instruction: A lesson design handbook for the elementary grades. Critical Thinking Books and Software.

Syukri, M., Halim, L., \& Meerah., T.S.M. (2013). Pendidikan STEM dalam entrepreneurial science thinking "ESciT": Satu perkongsian pengalaman dari UKM untuk Aceh [STEM education in entrepreneurial science thinking "ESciT": An experience shared from UKM for Aceh]. Aceh Development International Conference, 2013, 105-112.

Taherdoost, H. (2016). Validity and reliability of the research instrument; How to test the validation of a questionnaire/survey in a research study. International Journal of Academic Research in Management, 5(3), 28-36. 
Jamilah AHMAD, Nyet Moi SIEW. An entrepreneurial science thinking module based on the socioscientific issues approach with thinking wheel map for primary school students in STEM education

PROBLEMS

OF EDUCATION

IN THE $21^{\text {st }}$ CENTURY

Vol. 80 , No. 1, 2022

Topçu, M. S., Foulk, J. A., Sadler, T. D., Pitiporntapin, S., \& Atabey, N. (2018). The classroom observation protocol for socioscientific issue-based instruction: development and implementation of a new research tool. Research in Science \& Technological Education, 36(3), 302-323. https://doi.org/10.1080/02635143.2017.1399353

Vygotsky, L. (1978). Mind in society: The development of higher psychological processes. Harvard University Press. https://doi.org/10.1016/S0140-6736(10)60669-1

Yurdugül, H. (2008). Minimum sample size for Cronbach's coefficient alpha: A Monte Carlo study. Hacettepe Egitim Dergisi, 35, 397-405.

Zeidler, D. L. (2016). STEM education: A deficit framework for the twenty first century? A sociocultural socioscientific response. Cultural Studies of Science Education, 11(1), 11-26. https://doi.org/10.1007/s11422-014-9578-z

Zeidler, D. L., \& Nichols, B. H. (2009). Socioscientific issues: Theory and practice. Journal of Elementary Science Education, 21(2), 49-58. https://doi.org/10.1007/bf03173684

Zeidler, D. L., Sadler, T. D., Applebaum, S., \& Callahan, B. E. (2009). Advancing reflective judgment through socioscientific issues. Journal of Research in Science Teaching, 46(1), 74-101. https://doi.org/10.1002/tea.20281

Zeidler, D. L., Sadler, T. D., Simmons, M. L., \& Howes, E. V. (2005). Beyond STS: A researchbased framework for socioscientific issues education. Science Education, 89(3), 357-377. https://doi.org/10.1002/sce.20048

Zeidler, D. L. \& Keefer, M. (2003). The role of moral reasoning on socioscientific issues and discourse in science education. Kluwer Academic.

\section{Appendix}

\begin{tabular}{|c|c|c|c|}
\hline Stage & The Task & Sample Answers & STEM Element \\
\hline \multicolumn{4}{|c|}{ Observation } \\
\hline 1 (a) & $\begin{array}{l}\text { State the materials used to } \\
\text { make the car. }\end{array}$ & $\begin{aligned} & \text { i. } \text { Iron and aluminium for the } \\
& \text { body of the car } \\
& \text { ii. } \text { Rubber for tires } \\
& \text { iii. } \text { Plastic for car interior } \\
& \text { materials. }\end{aligned}$ & \multirow{3}{*}{$\begin{array}{l}\text { Science [S] } \\
\text { i. An energy source is } \\
\text { needed to power a car. } \\
\text { Technology [T] } \\
\text { i. Fuel system - } \\
\text { supplies petrol } \\
\text { or diesel to the } \\
\text { engine. }\end{array}$} \\
\hline 1 (b) & State the design of the car. & $\begin{aligned} \text { i. } & \text { Aerodynamic design } \\
\text { ii. } & \text { Round and square lamp. } \\
\text { iii. } & \text { Different car body styles - jeep, } \\
& \text { van, sedan etc }\end{aligned}$ & \\
\hline $1(\mathrm{c})$ & $\begin{array}{l}\text { State the features found } \\
\text { on the car. }\end{array}$ & $\begin{aligned} \text { i. } & \text { The fossil fuel used is a non- } \\
& \text { renewable energy } \\
\text { ii. } & \text { Fuel combustion system } \\
\text { iii. } & \text { Side and tail mirrors reflect } \\
& \text { light behind a driver. } \\
\text { iv. } & \text { Use of GPS and Bluetooth } \\
& \text { technology in cars. }\end{aligned}$ & \\
\hline
\end{tabular}


Jamilah AHMAD, Nyet Moi SIEW. An entrepreneurial science thinking module based on the socioscientific issues approach with thinking wheel map for primary school students in STEM education

PROBLEMS

OF EDUCATION

IN THE $21^{\text {st }}$ CENTURY Vol. 80 , No. 1,2022

\begin{tabular}{|c|c|c|c|c|}
\hline \multicolumn{5}{|c|}{ New Ideas } \\
\hline 2 (a) & $\begin{array}{l}\text { Explain the advantages } \\
\text { of using the specified } \\
\text { materials to make a car. }\end{array}$ & & $\begin{array}{l}\text { The material is readily } \\
\text { available. } \\
\text { Lightweight material is suitable } \\
\text { for car manufacturing. } \\
\text { Appropriate costs. }\end{array}$ & \multirow{3}{*}{\begin{tabular}{|ll} 
Science [S] \\
i. & The principle \\
& of light - can be \\
& reflected on flat, \\
& hard and shiny \\
& surfaces. \\
ii. & GPS technology \\
& allows users \\
access to live route & maps.
\end{tabular}} \\
\hline $2(b)$ & $\begin{array}{l}\text { Explain the advantages } \\
\text { of using the stated car } \\
\text { design. }\end{array}$ & & $\begin{array}{l}\text { Less air resistance. } \\
\text { Cars can move fast. } \\
\text { The car looks stylish. }\end{array}$ & \\
\hline $2(c)$ & $\begin{array}{l}\text { Explain the advantages } \\
\text { of using the features } \\
\text { available on the car. }\end{array}$ & & $\begin{array}{l}\text { Energy sources are readily } \\
\text { available. } \\
\text { Energy resources can be } \\
\text { obtained at affordable costs. } \\
\text { The use of mirrors and } \\
\text { technology in the car facilitates } \\
\text { the user while driving and } \\
\text { keeps the driver in a safe } \\
\text { condition. } \\
\text { Burning fuel to produce energy. }\end{array}$ & \\
\hline \multicolumn{5}{|c|}{ Innovation } \\
\hline 3 (a) & $\begin{array}{l}\text { Choose } 3 \text { ideas that can be } \\
\text { modified or improved. }\end{array}$ & & $\begin{array}{l}\text { Consumption of fossil fuel. } \\
\text { Burning fuel to produce energy. } \\
\text { Car design. }\end{array}$ & \\
\hline 3 (b) & $\begin{array}{l}\text { Make an evaluation of the } \\
\text { selected ideas. }\end{array}$ & & $\begin{array}{l}\text { Can be modified to meet the } \\
\text { future of modernity } \\
\text { Fuel combustion can be } \\
\text { replaced with more energy } \\
\text {-efficient methods. } \\
\text { Can be modified to be more } \\
\text { environmentally friendly. }\end{array}$ & \\
\hline \multicolumn{5}{|c|}{ Creativity } \\
\hline 4 (a) & $\begin{array}{l}\text { Sketch and label } 3 \\
\text { features for a future car. }\end{array}$ & & $\begin{array}{l}\text { Aerodynamic and modern } \\
\text { design, the use of durable } \\
\text { materials. } \\
\text { Water is used as an energy } \\
\text { source to produce hydrogen. } \\
\text { Use of water hydrolysis } \\
\text { technology, GPS navigation, } \\
\text { safety operator assistance } \\
\text { system }\end{array}$ & \multirow{2}{*}{$\begin{array}{l}\text { Science [S] } \\
\text { Hydrogen vehicles for } \\
\text { better fuel economy than } \\
\text { conventional vehicles. } \\
\text { Technology [T] } \\
\text { i. Water hydrolysis } \\
\text { technology: cars } \\
\text { use water and } \\
\text { car batteries to } \\
\text { generate electrical } \\
\text { energy. } \\
\text { Engineering [E] } \\
\text { i. Sketching a car. } \\
\text { Mathematics [M] } \\
\text { i. Set the price for } \\
\text { the prototype } \\
\text { according to } \\
\text { market price. } \\
\text { ii. } \\
\text { Estimate the speed } \\
\text { of the car. } \\
\text { Speed = }\end{array}$} \\
\hline $4(b)$ & $\begin{array}{l}\text { State the name of the } \\
\text { product, the price offered } \\
\text { and the target group of } \\
\text { buyers. }\end{array}$ & & $\begin{array}{l}\text { Any logical answer is } \\
\text { acceptable }\end{array}$ & \\
\hline
\end{tabular}


Jamilah AHMAD, Nyet Moi SIEW. An entrepreneurial science thinking module based on the socioscientific issues approach with thinking wheel map for primary school students in STEM education

PROBLEMS

OF EDUCATION

IN THE $21^{\text {st }}$ CENTURY

Vol. 80 , No. 1,2022

\begin{tabular}{|c|c|c|c|c|}
\hline Value & & & & \\
\hline 5 (a) & $\begin{array}{l}\text { State the benefits of the } \\
\text { product to society from } \\
\text { the aspect of cost savings. }\end{array}$ & $\begin{array}{l}\text { i. } \\
\text { ii. } \\
\text { iii. }\end{array}$ & $\begin{array}{l}\text { Car prices are lower. } \\
\text { Cars are affordable for many } \\
\text { people. } \\
\text { The use of water can save fuel } \\
\text { costs. }\end{array}$ & \multirow{3}{*}{ 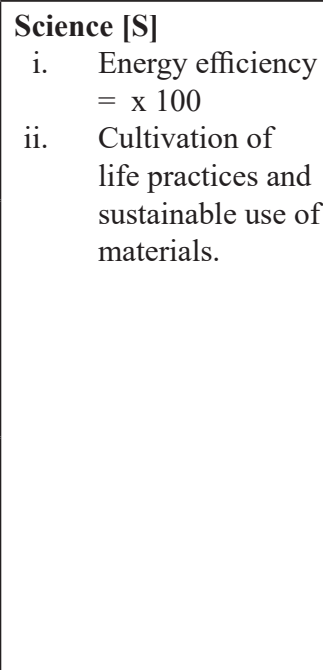 } \\
\hline $5(b)$ & $\begin{array}{l}\text { State the benefits of the } \\
\text { product to society from } \\
\text { the aspect of product } \\
\text { function. }\end{array}$ & $\begin{array}{l}\text { i. } \\
\text { ii. } \\
\text { iii. }\end{array}$ & $\begin{array}{l}\text { The car is safe to drive even on } \\
\text { potholed roads. } \\
\text { Cars make it easier for users to } \\
\text { reach their destinations. } \\
\text { The durable car body makes it } \\
\text { safer. }\end{array}$ & \\
\hline 5 (b) & $\begin{array}{l}\text { State the benefits of the } \\
\text { product to society from } \\
\text { the aspect of values and } \\
\text { ethics in product creation. }\end{array}$ & & $\begin{array}{l}\text { Renewable energy } \\
\text { consumption. } \\
\text { Maximum energy efficiency } \\
\text { use. } \\
\text { Cars do not pollute the } \\
\text { environment. }\end{array}$ & \\
\hline
\end{tabular}

Cite as: Ahmad, J., \& Siew, N. M. (2022). An entrepreneurial science thinking module based on the socioscientific issues approach with thinking wheel map for primary school students in STEM education. Problems of Education in the $21^{\text {st }}$ Century, 80(1), 30-51. https://doi.org/10.33225/pec/22.80.30

Jamilah Ahmad

MEd. (Science Education), PhD Candidate, Faculty of Psychology and Education, University of Malaysia Sabah, 88400, Kota Kinabalu, Sabah, Malaysia.

E-mail: jamilahahmad99@gmail.com

ORCID: https://orcid.org/0000-0003-0555-550X

Nyet Moi Siew

(Corresponding author)
$\mathrm{PhD}$, Associate Professor, Faculty of Psychology and Education, University of

Malaysia Sabah, 88400, Kota Kinabalu, Sabah, Malaysia.

E-mail: sopiah@ums.edu.my

ORCID: https://orcid.org/0000-0003-1989-5863 